\title{
Mollusca, Nudibranchia: New records and southward range extensions in Santa Catarina, southern Brazil
}

\author{
Vinicius Padula ${ }^{1 *}$, Juliana Bahia ${ }^{2}$, Camila Vargas ${ }^{3}$ and Alberto Lindner ${ }^{3}$ \\ 1 Zoologische Staatssammlung München, Mollusca Sektion, Münchhausenstr. 21, 81247, München, Germany \\ 2 Universidade Federal do Rio de Janeiro, Departamento de Biologia Marinha, Laboratório de Benthos, Ilha do Fundão. CEP 21949-900. Rio de \\ Janeiro, RJ, Brazil. \\ 3 Universidade Federal de Santa Catarina, Departamento de Ecologia e Zoologia - CCB, Edifício Fritz Muller. CEP 88040-970. Florianópolis, SC, \\ Brazil. \\ * Corresponding author: E-mail: viniciuspadula@yahoo.com
}

\begin{abstract}
Nudibranch molluscs constitute a group of marine gastropods little studied in most of the Brazilian coast extension. Up to date, only ten species are known from Santa Catarina state, southern Brazil. This work presents four new records of nudibranchs from this region: Aeolidiella indica Bergh, 1988; Berghia rissodominguezi Muniain and Ortea, 1999; Chromodoris paulomarcioi Domínguez, García and Troncoso, 2006 and Tambja stegosauriformis Pola, Cervera, and Gosliner, 2005, expanding the known geographic distribution of the last two species more than $900 \mathrm{~km}$ southward.
\end{abstract}

The Santa Catarina state, southern Brazil (26-29 S), represents the southernmost limit of rocky shores in the tropical Southwest Atlantic (Floeter et al. 2008). Yet, the marginal reef sites in the region have only recently started to be studied in more detail, resulting in new records of tropical invertebrates (Rieger and Giraldi 1997) and particularly reef fishes (Barneche et al. 2009). In this study, we report four new records of nudibranchs from Santa Catarina state (Figure 1).

Nudibranchs constitute marine gastropods that lost completely the shell in the adult stage and their defense is given mostly by toxic products obtained from their prey, as cnidarians and sponges (Behrens 2005). Currently, approximately 100 nudibranch species are reported from Brazil (DaCosta et al. 2010) while around 3000 are known worldwide (Wagële and Klussman-Kolb 2005). Most of the available data on Brazilian nudibranchs result from the studies of Ernst and Eveline Marcus done between the 1950 and 1980 decades, most of them at southeastern Brazil (e.g. Marcus 1955; 1957). Recent studies resulted in new records and the description of new species from this region (Padula and Santos 2006; García García et al. 2008; DaCosta et al. 2010, Alvim et al. 2011) while northern, northeastern and southern Brazilian coasts remain poorly studied.

Despite the lack of studies focused on nudibranchs in southern Brazil, two of the firstly species know from Brazil, Armina muelleri (Ihering, 1886) and Thordisa ladislavii (Ihering, 1886), were described based on material from Santa Catarina state (Ihering 1886). The same work reported Doris verrucosa Linnaeus, 1758 (as Staudoris verrucosa) and Marionia cucullata (Couthouy, 1852) (as Tritonia cucullata) from the region (Ihering 1886). After a gap of almost a century, Marcus (1977) listed Dendrodoris krebsii (Mörch, 1863) and only 25 years later two other nudibranch species have been reported for Santa Catarina: the aeolids Dondice occidentalis (Engel, 1823) by Wiggers and Magalhães (2003) and Spurilla neapolitana (Delle
Chiaje, 1823), by Pimpão and Magalhães (2004). In 2006, the dorid Hypselodoris lajensis Troncoso, García and Urgorri, 1998 was reported to the Arvoredo Marine Biological Reserve (Domínguez et al. 2006) and one year later, DaCosta et al. (2007) described the subspecies Flabellina engeli lucianae, with distribution from Rio de Janeiro to Santa Catarina. Finally, a recent checklist added Polycera aurisula Marcus, 1957 to the list of marine

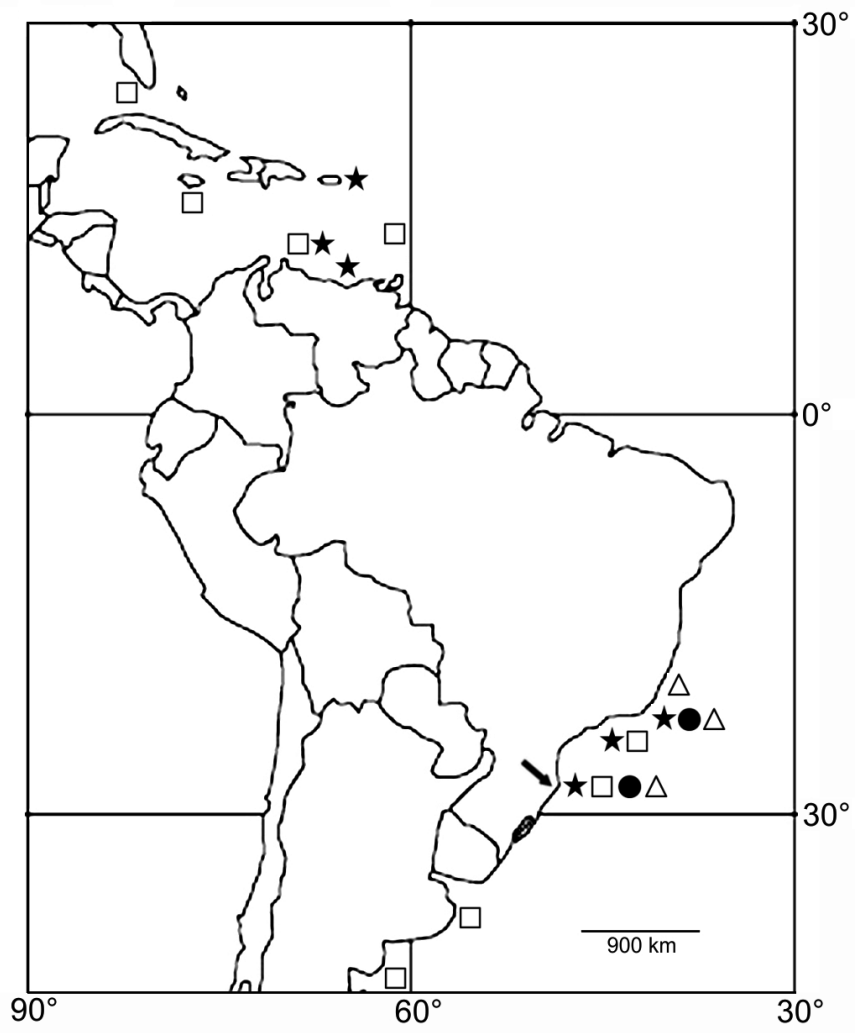

FIGURE 1. Geographic distribution of Aeolidiella indica ( $\star$ ), Berghia rissodominguezi ( $\square$ ), Chromodoris paulomarcioi ( $)$, Tambja stegosauriformis $(\triangle)$ with indication of the news records from Santa Catarina state. Aeolidiella indica is a cosmopolitan species, records from the Pacific not indicated. 
mollusks from Santa Catarina state (Agudo-Padrón et al. 2009), resulting in a total of 10 nudibranch species reported for the region up to date.

Due this scenario, the authors and collaborators conducted collections at Santa Catarina state, including the Arvoredo Marine Biological Reserve and adjacent areas under the permission 22583-1 of the ICMBio/SISBIO, Brazilian Ministery of Environment, with the objective to expand the knowledge on nudibranchs in this region. Material is deposited in the malacological collections of the Museu Nacional, Universidade Federal do Rio de Janeiro (MNRJ) and the Museu de Zoologia, Universidade de São Paulo (MZUSP). Collections at Praia da Armação (2744'52.24" S, 48 29'55.93” W) resulted in two species previously unknown from southern Brazil: Aeolidiella indica Bergh, 1888 and Berghia rissodominguezi Muniain and Ortea, 1999. Two specimens of $A$. indica (Figure 2A) were collected intertidally, on 20 April 2007, by V. Padula and J. Bahia (MNRJ 11300; 8-17 mm long, alive). A single specimen of $B$. rissodominguezi (Figure 2B) was collected at the same locality and date (MZSP 96627; $15 \mathrm{~mm}$ long alive). Aeolidiella indica is a circumtropical species reported in Brazil from Rio de Janeiro and São Paulo states (Marcus and Marcus 1967; García García et al. 2008). Berghia rissodominguezi occur from Florida to Argentina and has been reported in Brazil at São Paulo state, as Berghia coerulescens by Marcus (1957) (see Muniain and Ortea 1999).

SCUBA divings at Arvoredo Marine Biological Reserve and adjacent areas, conducted in December 2009, resulted on the collection of other two species previously unknown from southern Brazil: Chromodoris paulomarcioi
Domínguez, García and Troncoso, 2006 and Tambja stegosauriformis Pola, Cervera and Gosliner, 2005. Up to now, C. paulomarcioi was only known from its typelocality at Búzios, Rio de Janeiro state, Brazil. A single specimen (Figure 2C) was collected at $6 \mathrm{~m}$ depth at Saco do Engenho (271'08" S, 48 $22^{\prime} 13^{\prime \prime}$ W), 10 December 2009, by F. Azevedo and J. Carraro (MZSP 96626; 25 mm long preserved). Chromodoris paulomarcioi is very similar to the Caribbean species Chromodoris grahami Thompson, 1980 , of which in fact may be a synonym. A comparative study is being conducted to clarify this question. The species Tambja stegosauriformis, previously known from Guarapari, Espírito Santo state (Rudman 2005) and the Cabo Frio region, Rio de Janeiro state (Pola et al. 2005), southeastern Brazil, was found at Ilha Deserta (27 $16^{\prime} 22^{\prime \prime}$ $\mathrm{S} / 48^{\circ} 19^{\prime} 58^{\prime \prime} \mathrm{W}$ ). One specimen was collected (Figure 2D) at $12 \mathrm{~m}$ depth, 09 December 2009, by M. Kammers and L. Zago (MZSP 96625; $40 \mathrm{~mm}$ long preserved).

The present records of Chromodoris paulomarcioi and Tambja stegosauriformis expand their known geographic distribution more than $900 \mathrm{~km}$ southward (Figure 1). In addition, the distribution of some nudibranch species from the tropical Caribbean to southern Brazil, as Dondice occidentalis and Berghia rissodominguezi, the last one occurring also at the north of Argentina, suppose that they tolerate different environmental - water temperature and currents - and ecological conditions, as observed for some western Atlantic reef fishes (Barneche et al. 2009). However, the connectivity between Caribbean, northern and southern Brazil populations of nudibranchs was never investigated, representing an interesting subject for new studies.
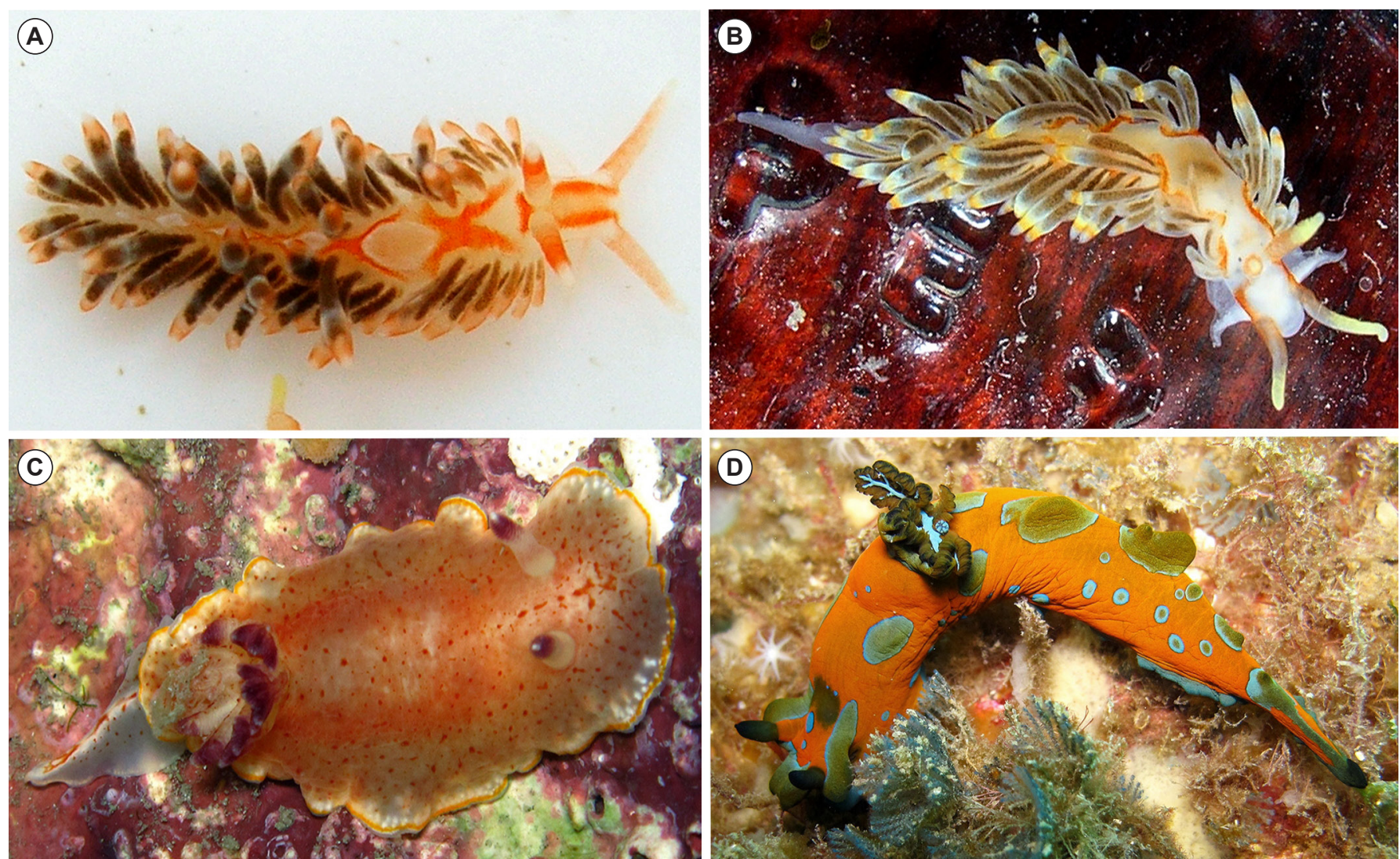

FIGURE 2. New nudibranch records from Santa Catarina state, southern Brazil. A. Aeolidiella indica from Praia da Armação (MNRJ $11300 ; 17$ mm long alive); B: Berghia rissodominguezi from Praia da Armação (MZSP 96627; 15 mm long alive); C. Chromodoris paulomarcioi from Saco do Engenho (MZSP 96626; 25 mm long preserved); D. Tambja stegosauriformis from Ilha Deserta (MZSP 96625; 40 mm long preserved). Photos: A and B. Vinicius Padula; C. by João L.F. Carraro; D. by Leandro Zago. 
ACKNowledgments: We thank Chico Mendes Institute for Biodiversity Conservation, Brazilian Ministery of Environment (ICMBio) for the permission to collect material in Arvoredo Marine Biological Reserve; Marcelo Kammers, Leandro Zago (REBIO Arvoredo/ICMBio), Fernanda Azevedo (UFRJ) and João L.F. Carraro (UFRGS) for their assistance and photos in the field; Ignacio Agudo-Padrón for information on some species records and Franklin Santos (UFES) for valuable comments on the manuscript. This project is funded by grants from Fundação de Amparo à Pesquisa e Inovação do Estado de Santa Catarina (FAPESC; 4302/20108) and FAPESC/National Council for Scientific and Technological Development (CNPq-Brasil) (17.415/2009-7) to Alberto Lindner and scholarships from CNPq-Brasil and Deutscher Akademischer Austausch Dienst (DAAD-Germany) to Vinicius Padula and Brazilian Federal Agency for the Support and Evaluation of Graduate Education (CAPES) to Juliana Bahia.

\section{LITERATURE Cited}

Agudo-Padrón, A.I., M.S. Bleicker and K. Saafeld. 2009. Recent marine molluscs of Santa Catarina State, SC, southern Brazil region: a comprehensive synthesis and check list. VISAYA Net 3: 1-17.

Alvim, J., V. Padula and A. Pimenta. 2011. First record of the genus Onchidoris (Gastropoda: Nudibranchia: Onchidorididae) from the South Atlantic Ocean, with the description of a new species from Brazil. Journal of the Marine Biological Association of the United Kingdom 91: 505-511.

Barneche, D.R., A.B. Anderson, S.R. Floeter, M. Silveira, D.F. Dinslaken and A. Carvalho-Filho. 2009. Ten new records of reef fish on the coast of Santa Catarina State, Brazil. Marine Biodiversity Records 2: e143.

Behrens, D.W. 2005. Nudibranch behavior. Jacksonville: New World Publications, Inc. 176 p.

Bergh, L.S.R. 1888. Malacologische Untersuchungen. Reisen im Archipel der Philippinen von Dr. Carl Gottfried Semper. Zweiter Theil. Wissenschaftliche Resultate. Band 2, Theil 3, Heft 16, 1 Hälfte: 755814.

DaCosta, S., C.M. Cunha, L.R.L. Simone and M. Schrödl. 2007. Computerbased 3-dimensional reconstruction of major organ systems of a new aeolid nudibranch subspecies, Flabellina engeli lucianae, from Brazil (Gastropoda: Opisthobranchia). Journal of Molluscan Studies 73(4): 339-353.

DaCosta, S., V. Padula and M. Schrödl. 2010. A new species of Hypselodoris and a redescription of Hypselodoris picta lajensis (Nudibranchia: Chromodorididae) from Brazil. The Veliger 51: 15-25.

Domínguez, M., F.J. García and J.S. Troncoso. 2006. Some aspects of the family Chromodorididae (Opisthobranchia: Nudibranchia) from Brazil, with description of a new species. Scientia Marina 70(4): 621634.

Floeter, S.R., L.A. Rocha, D.R. Robertson, J.C Joyeux, W.F. Smith-Vaniz, P. Wirtz, A.J Edwards, J.P. Barreiros, C.E.L. Ferreira, J.L. Gasparini, A. Brito, J.M. Falcón, B.W. Bowen and G. Bernardi. 2008. Atlantic reef fish biogeography and evolution. Journal of Biogeography 35: 22-47
García García, F.J., M. Domínguez Alvaréz and J.S. Troncoso. 2008. Opistobranquios de Brasil: Descripción y distribución de opistobranquios del litoral de Brasil y del Archipiélago Fernando de Noronha. Vigo: Feito, S.L. 215 p.

Ihering, H.v. 1886. Zur Kenntniss der Nudibranchien der brasilianischen Küste. Jahrbücher der Deutsche Malakozoologische Gesellschaft 13(3): 223-240.

Marcus, Er. 1955. Opisthobranchia from Brazil. Boletim da Faculdade de Filosofia, Ciências e Letras, Universidade de São Paulo, Zoology 207(20): 89-261.

Marcus, Er. 1957. On Opisthobranchia from Brazil (2). Journal of the Linnean Society of London, Zoology 43(292): 390-486.

Marcus, Ev. 1977. An annotated checklist of the western Atlantic warm water opisthobranchs. Journal of Molluscan Studies 4: 1-23.

Marcus, Ev. and Er. Marcus. 1967. American opisthobranch mollusks Part I, Tropical American opisthobranchs, Part II, Opisthobranchs from the Gulf of California. Studies in Tropical Oceanography 6(1-2): 1-256.

Muniain, C. and J. Ortea. 1999. First records of the genus Berghia Trinchese, 1877 (Opisthobranchia: Aeolidiidae) from Argentina, with description of a new species. Avicennia 10-11: 143-150.

Padula, V. and F.N. Santos. 2006. Three new records of Nudibranchia (Mollusca, Gastropoda) - additions on the Brazilian biodiversity. Biociências 14(2): 214-220.

Pola, M., J.L. Cervera and T.M. Gosliner. 2005. A new species of Tambja (Nudibranchia: Polyceridae: Nembrothinae) from southern Brazil. Journal of the Marine Biological Association of the United Kingdom 85(4): 979-984.

Pimpão, D.M. and A.R.M. Magalhães. 2004. Primeiro registro de Spurilla neapolitana (Gastropoda, Nudibranchia) no litoral catarinense, SC Brasil. Biociências 12(2): 181-183.

Rieger, P.J. and J.L.B. Giraldi. 1997. Calcinus tibicen (Herbst, 1791) e Paguristes tortugae Schmitt, 1933, novo registro de Diogenidae (Decapoda, Anomura) para o litoral de Santa Catarina, Brasil. Nauplius 5(2): 159-161.

Rudman, W.B. 2005. Tambja stegosauriformis Pola, Cervera \& Gosliner, 2005. In Sea Slug Forum. Australian Museum, Sydney. Electronic database accessible at http://www.seaslugforum.net/factsheet/ tambsteg. Captured on 10 May 2011.

Wagële, H. and A. Klussmann-Kolb. 2005. Opisthobranchia (Mollusca, Gastropoda) - more than just slimy slugs. Shell reduction and its implications on defence and foraging. Frontiers in Zoology 2(3): 1-18.

Wiggers, F. and A.R.M. Magalhães. 2003. Novas ocorrências de moluscos no litoral de Santa Catarina, Brasil. Biotemas 16(1): 81-89.

RECEIVED: July 2011

LAST REVISED: August 2011

ACCEPTED: September 2011

Published online: December 2011

EDITORIAL RESPONSIBILITY: Luis Ernesto Arruda Bezerra 